two three times daily for another week, then returning to the first dosage. Uterine massage was given by forcing organ against and kneading it through abdominal wall, April 6, $12,19,27$, and May 3 and 10.

May 20, 1912: Menses appeared with fair flow for a day. Patient has taken on quite a little weight and feels well. Massage has been stopped. Extract of luteum is continued.

Patient had sensation of approaching menses in .June, but only a pink show. She had mild epistaxis. General condition is good; she seems to be rounding out. Becoming discouraged, patient abandoned treatment.

Extract of luteum treatment was advised and started again in September, 1912. Lterus seems larger and cervix longer than in June. Last part of October patient had slight menstrual show, first since June.

Nov. 3, 1912: Patient noticed more sexual feeling last month.

Pregnancy.-Nov. 25, 1912: No menses since show in October. Patient very much stouter, breasts enlarged, uterus larger, cervix longer. Pregnancy suspected and cautions given.

Jan. 24, 1913: Uterus much larger, size of large pear, cervix long and firm. Breasts much larger; hips larger; general appearance of woman's figure instead of boy's. Side view, prominence above pubes, as in three and a half to four months' pregnancy.

Feb. 1, 1913: Patient thought she felt motion. Breasts quite large, areola darker.

Feb. 9, 1913: Patient felt motion distinctly.

Feb. 14, 1913: Patient noticed fluid in breast. Pregnancy continued normally until May 26, when miscarriage threatened after strenuous day of house-cleaning.

July 2, 1913: Uterine pains started at about 4 a. m.; duration of about fifteen seconds and about half an hour or more apart. At 7:30 :l. m., pains were twenty minutes apart, rather regular, lasting one-half minute, os slightly open. Patient was sent to George Washington University Hospital at about 9 a. $m$. Pains were ten minutes apart, harder, and lasting about three-quarters to one minute. Expulsion pains, very strong, lasting from one to two minutes, began about $3: 30$ p. m. At 6 p. $\mathrm{m}$. patient was delivered normally of a boy weighing 6 pounds, 2 ounces. There was no tear of cervix or perineum. Placenta delivered ten minutes later normally. Mother and baby made an uneventful anä perfect recovery and left the hospital in two weeks.

Nov. 5, 1913: Baby well, strong and yood, weighs 14 pounds. Mother's condition excellent; has retained her weight and has nursed the baby from birth.

The Farragut.

\section{EASILY PREPARED DILUTING FLUID FOR COUNTIŇG RED CELLS}

James G. Callison, M.D., New YoRK

Text-books on clinical diagnosis usually give two diluting fluids for making the erythrocyte count in blood-work. These are Toisson's and Hayem's solutions. Toisson's fluid is difficult to prepare, as weighing the stipulated $25 \mathrm{mg}$. of methyl violet requires great care to secure the necessary accuracy, and more delicate scales than the average laboratory possesses. Then it is not always permanent, as molds may grow in it, forming precipitates. Hayem's solution has no added coloringmatter, and so the cells are not brought into clear relief. With this fluid it is also difficult to differentiate the white and red cells. I have for some time been using a dilutingfluid that is easily prepared, keeps permanently, and has all the advantages of either Toisson's or Hayem's solutions. The formula follows:

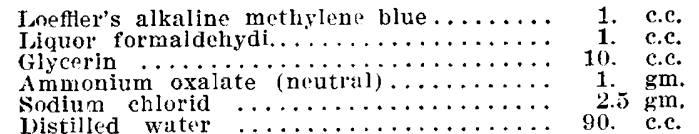

The various itgredients are adled to the distilled water and allowed to stand until solution occurs. After being filtered, the preparation is ready to use. This gives a diluting. fluid of specific gravity about 1.045-suffiently heavy to prevent a too rapid sedimentation of the red celis. If for any reason a diluting fluid of less specific gravity is desired, the glycerin and sodium chlorid may be reduced proportionally until the desired density is obtained. The preparation is permanent, easily prepared, and brings out the red cells in sharp relief, making the count easy. The red and white cells are also well difierentiated.

128 East Fifty-Seventh Strect.

\section{A CASE OF DORSAL DISLOCATION OF PROXIMAL PHALANX OF GREAT TOE}

Don W. Deal, M.D., Springfield, Ill.

C. T., aged 14, from Tower Hill, Ill., came into my service with a painful and swollen foot due to a horse falling on it.

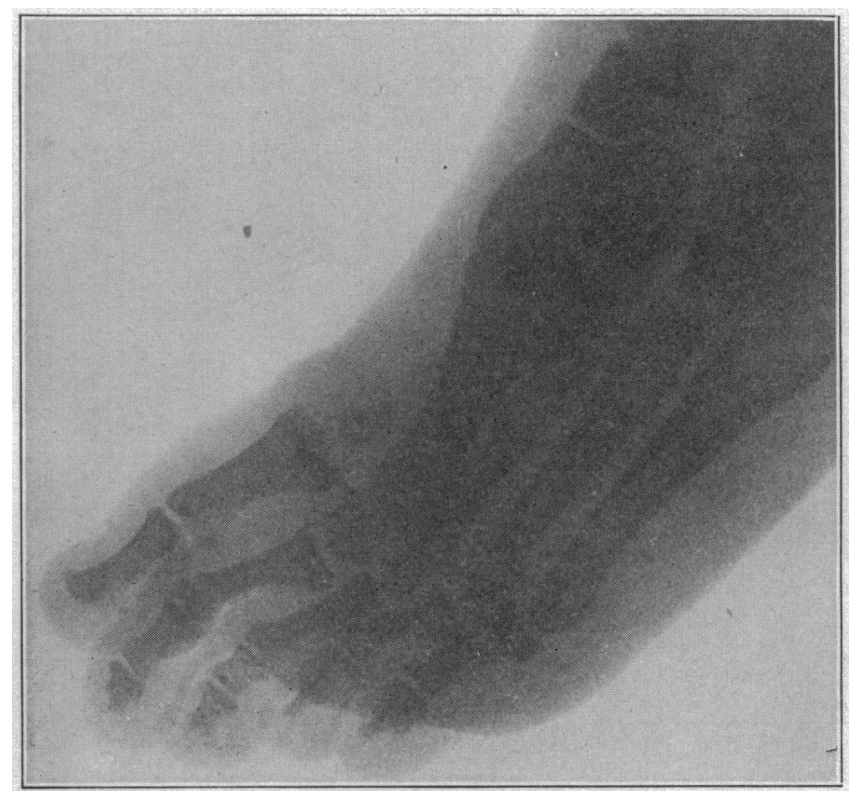

Fig. 1.-Dorsal dislocation of proximal phalanx of great toe

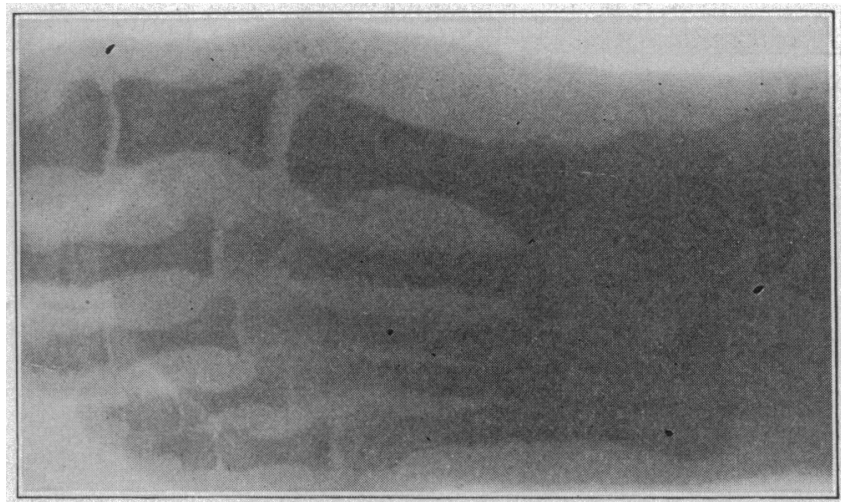

Fig. 2.-Same case after reduction.

Examination showed marked deformity of the right foot, and suspected fracture with dislocation. A roentgenogram by Dr. Fred O'Hara disclosed a dorsal dislocation of the proximal phalanx of the great toe, with a plantar displacement of the metatarsal, and a fracture of the distal end of the second metatarsal bone. Though Malogaigne calls attention to the fact that four out of ten cases of this type are irreducible, reduetion under general anesthesia was readily accomplished and the end-results are perfect.

Skillern ${ }^{1}$ refers to the rarity of the condition in his report of a case, and I am desirous of adding my case to those already reported, which now total twenty.

1. Skillern, P. G.: A Case of Dislocation of Proximal Phalanx of Great Toe, Trie Jocnsal A. M. A., Dee. 6, 1913, p. 2063. 